\title{
Technical photography for mural paintings: the newly discovered frescoes in Aci Sant'Antonio (Sicily, Italy)
}

\author{
A. Cosentino ${ }^{1, *}$ \\ M. Gil ${ }^{2}$ \\ M. Ribeiro ${ }^{3}$ \\ R. Di Mauro 4
}

${ }^{1}$ Cultural Heritage Science Open Source, Piazza Cantarella, 11 Aci Sant'Antonio, 95025, Italy

${ }^{2}$ Hercules Laboratory, Évora University, Palácio do Vimioso 8, 7000-809 Évora, Portugal

${ }^{3}$ Professional photographer ( freelancer)

${ }^{4}$ Professional architect (freelancer)

*antoninocose@gmail.com

\begin{abstract}
A cycle of 18th century frescoes, depicting the last days of Christ on earth, were recently discovered in Aci Sant'Antonio (Sicily, Italy). The paintings survive along the corners of an originally square chapel that was altered in the early 20th century, acquiring the current octagonal plan. This paper presents the results of the technical photography documentation of these wall paintings and illustrates the methodological challenges that were posed during their examination. Raking light photography was used to reveal the paintings' state of conservation, details of the plaster work and painting techniques. Ultraviolet fluorescence and infrared false color photography were also performed to evaluate areas of interest for further analytical and diagnostic studies. The first striking feature is the lack of giornate. Only pontate are clearly seen in all the scenes thus indicating that in the larger paint areas, a mixed of fresco and secco technique would have been used.
\end{abstract}

Fotografia técnica de pinturas murais: os frescos redescobertos em Aci Sant' Antonio (Sicília, Itália)

\section{Resumo}

Um ciclo de pinturas murais setecentistas, retratando os últimos dias de Cristo, foram descobertas recentemente em Aci Sant' Antonio (Sicilia, Itália). As pinturas localizam-se nos cantos de uma capela originalmente quadrada que foi alterada para uma planta octogonal nos inícios do século $X X$. Este artigo apresenta os resultados da documentação técnica dessas pinturas e ilustra os desafios metodológicos que foram colocados durante o seu exame. Fotografia de luz rasante foi usada para revelar o estado de conservação dos murais, detalhes da aplicação das argamassas e da técnica pictórica. Fotografias de fluorescência de ultravioleta e de falsa cor no infravermelho foram também realizadas para avaliar áreas de interesse para posteriores estudos analíticos e de diagnóstico. A primeira característica que se realça é a falta de giornatas. Apenas pontatas são claramente perceptíveis em todas as cenas, indiciando nas áreas de maiores dimensões o emprego de uma técnica mista (fresco e seco).

\section{Keywords}

Panoramic photography Infrared photography Ultraviolet photography Raking light photography Infrared false color Mural paintings

\section{Palavras-chave}

Fotografia panorâmica Fotografia de infravermelho Fotografia de fluorescência de ultravioleta Fotografia de luz rasante Falsa cor no infravermelho Pinturas murais

ISSN 2182-9942 


\section{Introduction}

This paper illustrates the application of technical photography (TP) [1-3] for the documentation and examination of a series of $18^{\text {th }}$ century frescoes. TP represents a collection of broadband spectral images realized with a modified full spectrum digital camera and using different lighting sources and filters to acquire images useful for art diagnostics, such as ultraviolet fluorescence and infrared false color photos. This study reports on the TP examination of a fresco cycle recently discovered in Sicily, while presenting an example of the capability that TP provides in the conservation and study of wall paintings.

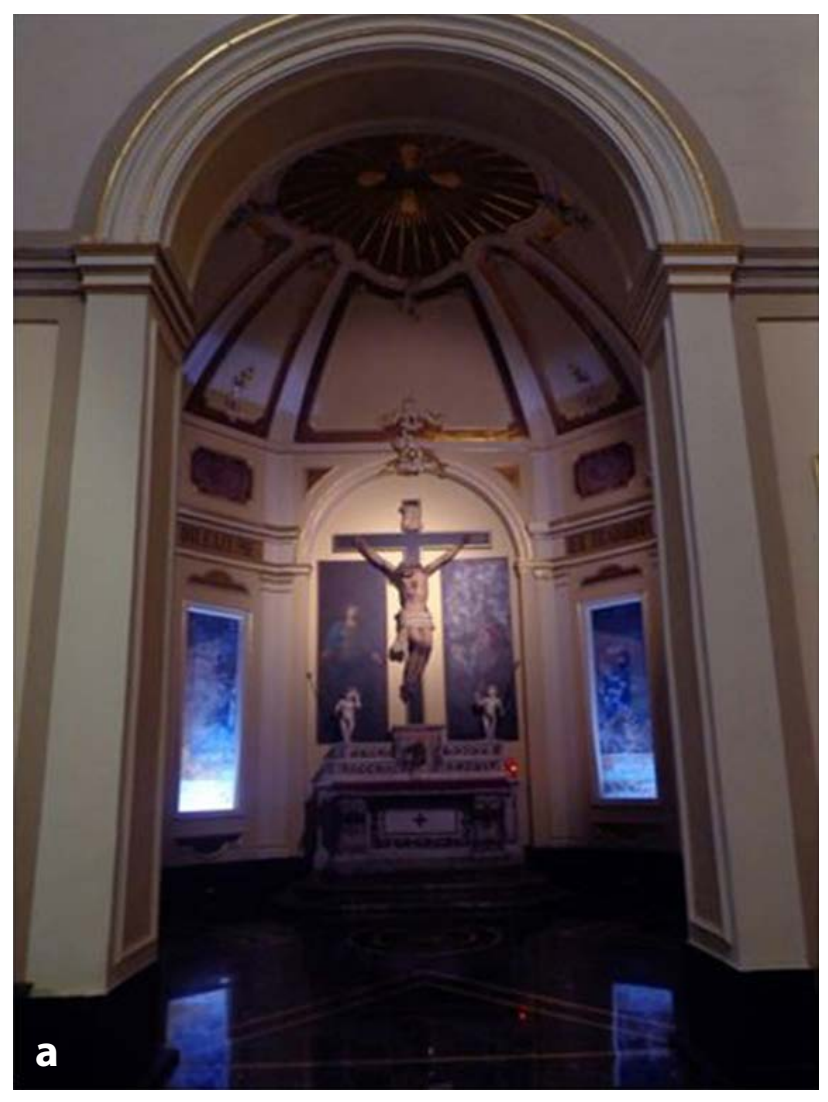

The examined frescoes were revealed during maintenance works carried out in 2012 in the Crucifix chapel of the Mother Church in Aci Sant'Antonio (Sicily). This church was originally built in 1566 and dedicated to Sant'Antonio. Soon after the destructive earthquake, which struck the south-east part of Sicily in 1693, the church was rebuilt with a Latin cross scheme composed of three naves, a transept and five chapels. The church preserves significant works of art, of which the most celebrated, the frescoes by Pietro Paolo Vasta (1697-1760), can be found decorating the apse. The Crucifix Chapel is located on the left of the transept and has an octagonal floor plan dated to the beginning of the $20^{\text {th }}$ century which has been realized within the original square plan (Figure 1). The

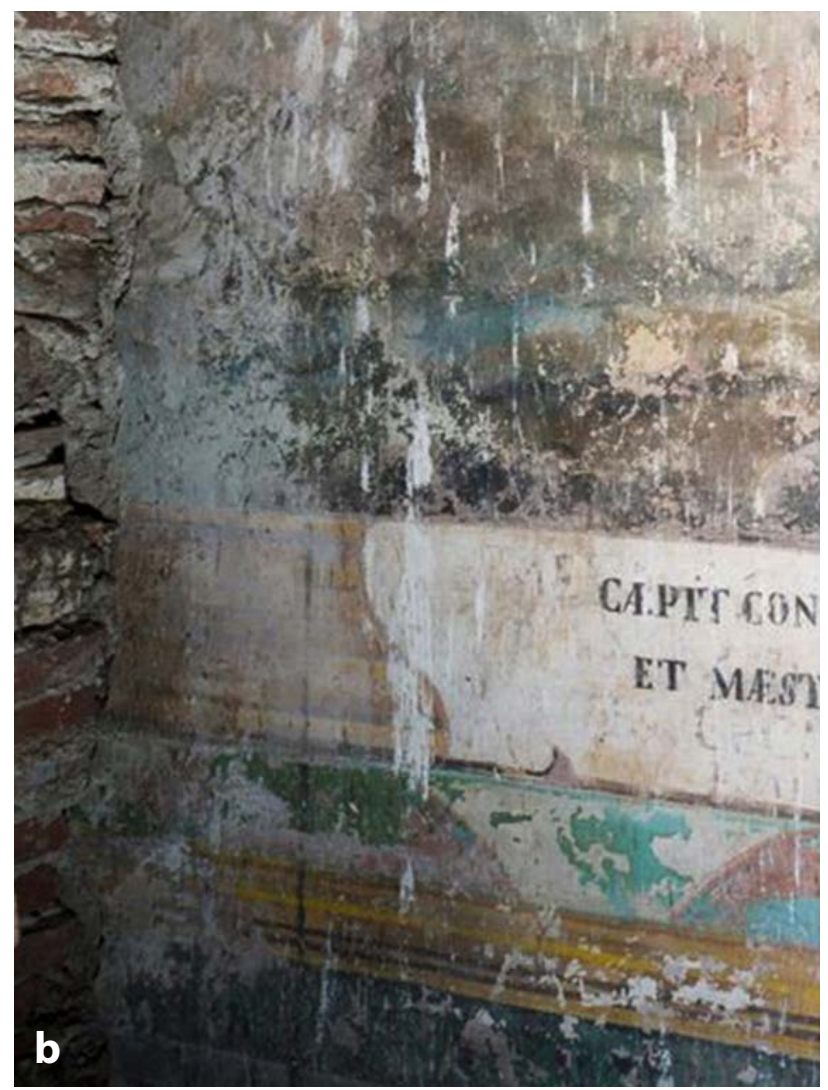

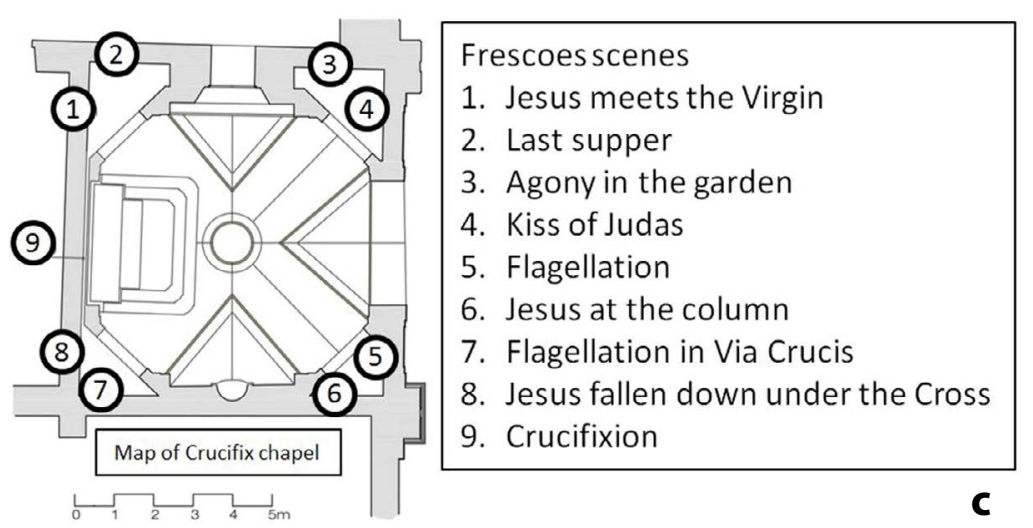

Figure 1. Crucifix Chapel, Mother Church, Aci Sant'Antonio (Sicily): a) photo of the chapel from the transept after the renovation; the frescoes are visible through the windows on the walls facing the four corners; $b$ ) border of the third scene, Agony in the garden; the original plaster was taken down in order to anchor the new wall; $c$ ) floor plan with the description of the scenes. 

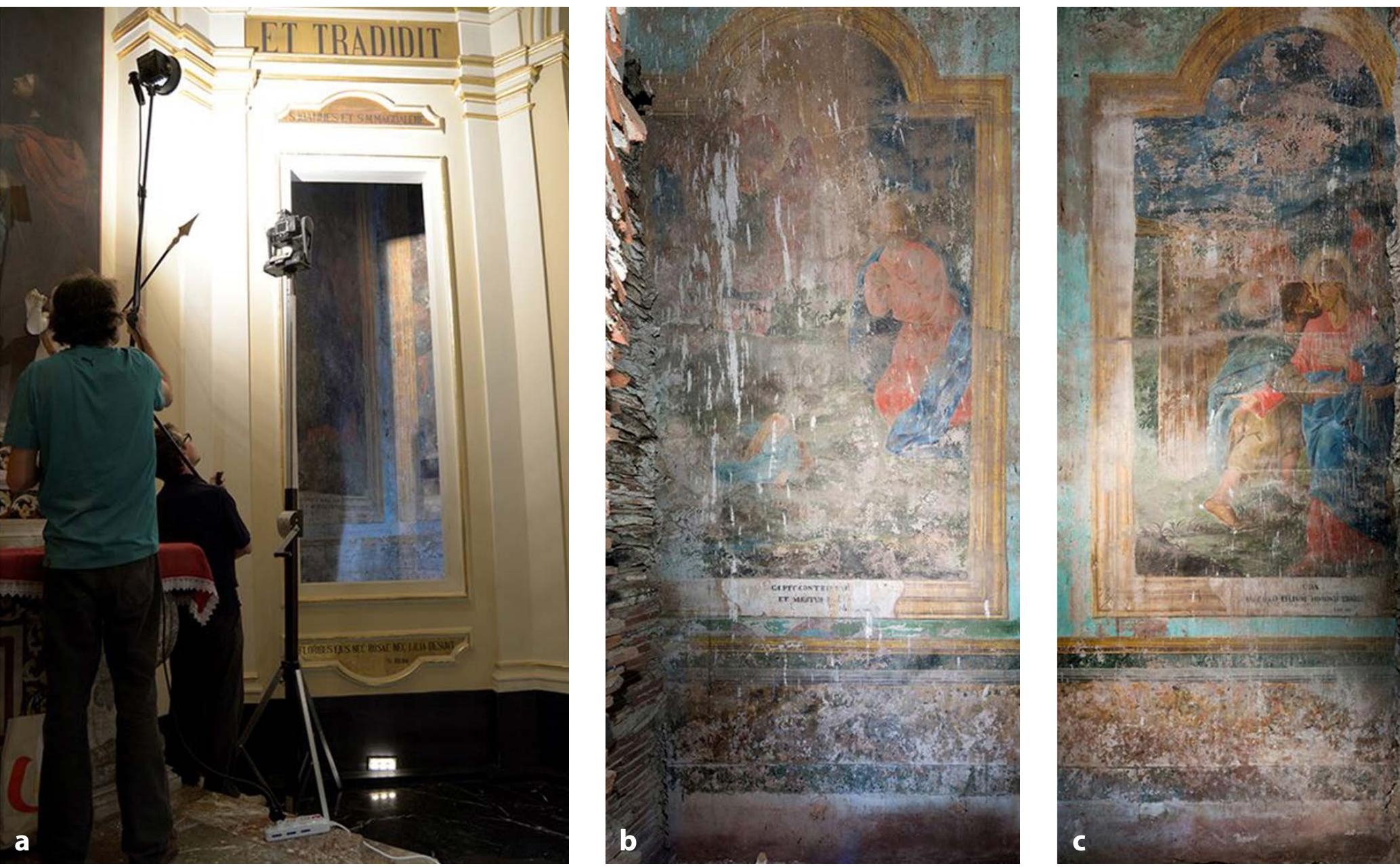

Figure 2. Crucifix chapel: a) NW corner. The early 20th century octagonal addition allows only a restricted field of view from outside. The camera was mounted on a telescopic pole and the documentation of the mural paintings was achieved with the mosaic method after shooting a stripe of vertical images; $b$ ) and $c$ ) SE corner, documentation of the frescoes realized with the panoramic method from inside the enclosure.

newly discovered mural paintings were preserved along the four corners of the original walls, while other sections of the fresco cycle have been irremediably lost, since new walls were added to the original ones to form the current octagonal plan. The inspection of the interface between the original walls and the later additions shows that no effort was made to preserve the original decorations (Figure 1). There are eight scenes which were preserved and they represent themes of the last days of earthly Christ: Last Supper; Jesus meets the Virgin; Agony in the garden; Kiss of Judas; Flagellation; Jesus at the column; Flagellation in Via Crucis; and Jesus fallen down under the Cross and Crucifixion.

From the examination of the account book of the Mother Church for the period between 1768 and 1792 [4] it was possible to attribute this cycle to the hand of Giuseppe Grasso Naso, pupil of Pietro Paolo Vasta. This paper adds to the sparse literature on the fresco technique used by this important workshop of mural painters in Sicily [5]. The most important figure was Pietro Paolo Vasta who opened his workshop in Acireale in 1734 and formed his apprentices, Michele Vecchio, Alessandro
Vasta (his son), and Giuseppe Grasso Naso. The present study deepens a preliminary study of these mural paintings [4] carried out in 2013 with portable X-ray fluorescence spectroscopy, fiber optics fluorescence spectroscopy and technical photography on two of the murals (4 and 5).

\section{Experimental}

Technical photography was performed in two spectral bands: visible (400-780 nm, VIS) and infrared (780-1100 $\mathrm{nm}, \mathrm{IR})$. The photographic methods implemented were: visible (VIS), raking light (RAK), infrared (IR), raking with infrared light (IR-RAK), ultraviolet fluorescence (UVF) and infrared false color (IRFC). The photos were acquired with a Nikon D800 DSLR (36 MP, CMOS sensor) digital camera modified "full spectrum" for ultraviolet-visible-infrared photography (extended sensitivity between about 360 and $1100 \mathrm{~nm}$ ). The filters used were: a) VIS and RAK photography: X-NiteCC1 filter; $b$ ) UVF photography: $\mathrm{B}+\mathrm{W} 420$ coupled with the X-NiteCC1; c) IR and IR-RAK: Heliopan RG1000. Two 
$1000 \mathrm{~W}$ halogen lamps were used for VIS, RAK, IR-RAK and IR photography; for ultraviolet (UV) photography, one high-flux $365 \mathrm{~nm}$ LED lamp was sufficient.

\section{Results and discussion}

\section{Photographic documentation}

After their discovery in 2012, the decision was made to preserve the early 20th century octagonal shape of the chapel and make the frescoes in the corners visible by way of large windows (Figure 2). While this solution is appealing for the visitors, since it provides an understanding of the modifications undergone by the chapel, it makes the photographic documentation of the paintings problematic because of the restrained field of view offered by the windows. The photographic documentation of all the murals is essential in order to formulate the plan for a conservation intervention to clean and consolidate the art works. On the first examination campaign [4], two of the paintings were documented using the panoramic photographic method. The camera was located outside the windows and at $5 \mathrm{~m}$ from the murals. The images were taken with a $200 \mathrm{~mm}$ lens and a panoramic head. While the quality of the images was satisfactory, the previous panoramic approach resulted in the documentation of only a narrow stripe of each painted wall since the window was substantially restraining the view.

During this study, the photographic documentation of the entirety of the wall paintings was achieved using the panoramic method. However, positioning the camera on a pole at $2.5 \mathrm{~m}$ (half the height of the fresco cycle) and inside the enclosure between the original walls and the $20^{\text {th }}$ century additions provided for an increased field of view. The camera photographed the opposite wall mounting a Nikon Nikkor $20 \mathrm{~mm}$ f3.5 lens and shooting a vertical sequence of five photos. This method provided a complete documentation of the corners. The stitched image was spatially calibrated using the Set Measurement Scale tool in Photoshop [6]. The Measurement Log tool provides any other measure needed such as calculation of areas, feature particularly useful to estimate the conservation intervention costs and time. The other technical photos, RAK, UVF, IR and IR-RAK, were realized from outside the windows with a mosaicking method. The camera was applied on a telescope pole and five photos covering the frescoes from the bottom to the top were shot, as allowed by the windows' frame (Figure 2). This solution does not allow the documentation of the entirety of the surface for each scene but just the stripe accessible through the window. Nonetheless, it was chosen because the documentation of the stripe was sufficient to the study of the paintings and the complete documentation would have been extremely difficult and lengthy.
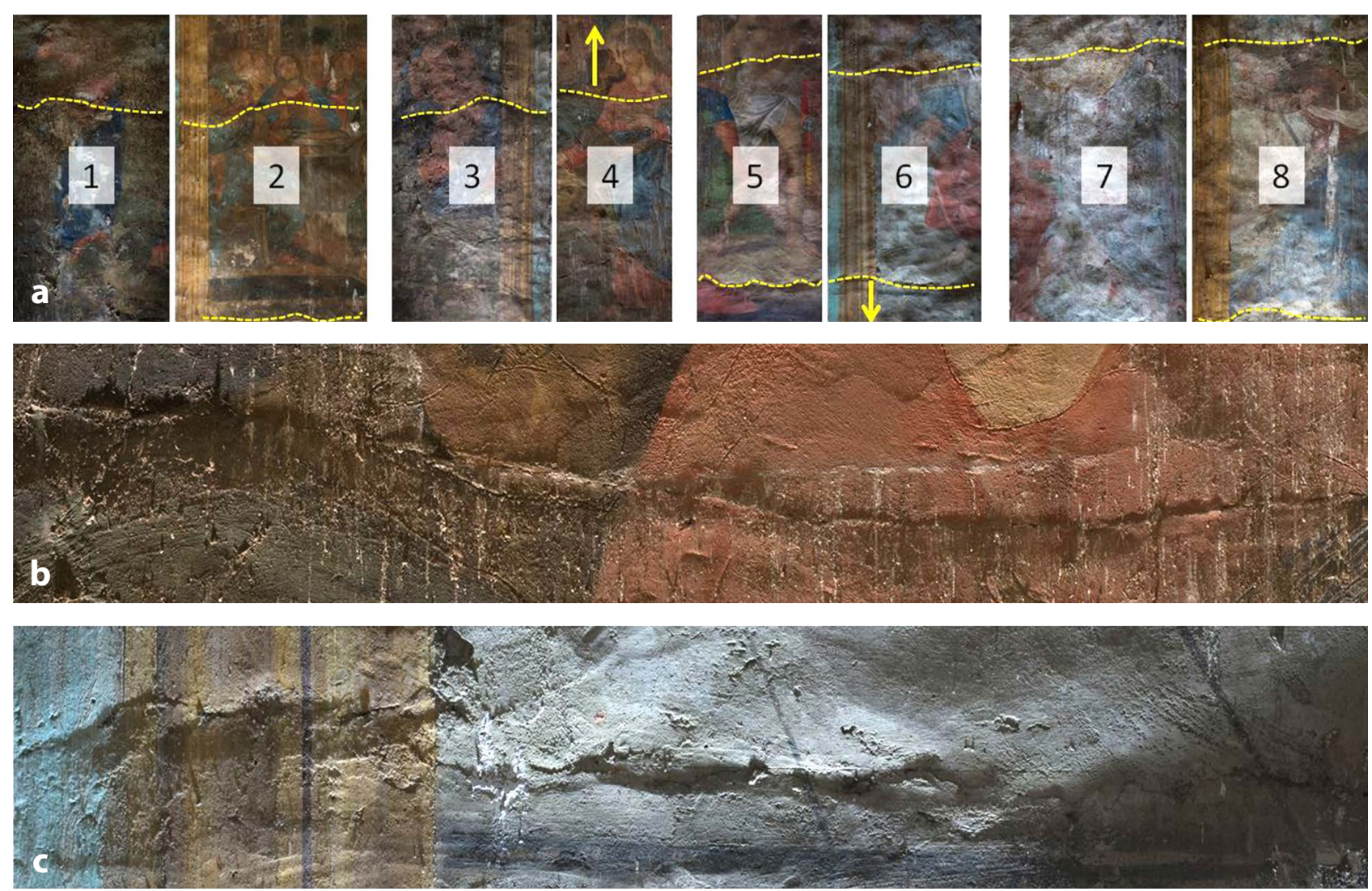

Figure 3. Maps of the pontate on the eight scenes $(a)$ and two details of pontate in scene $4(b)$ and $6(c)$. 


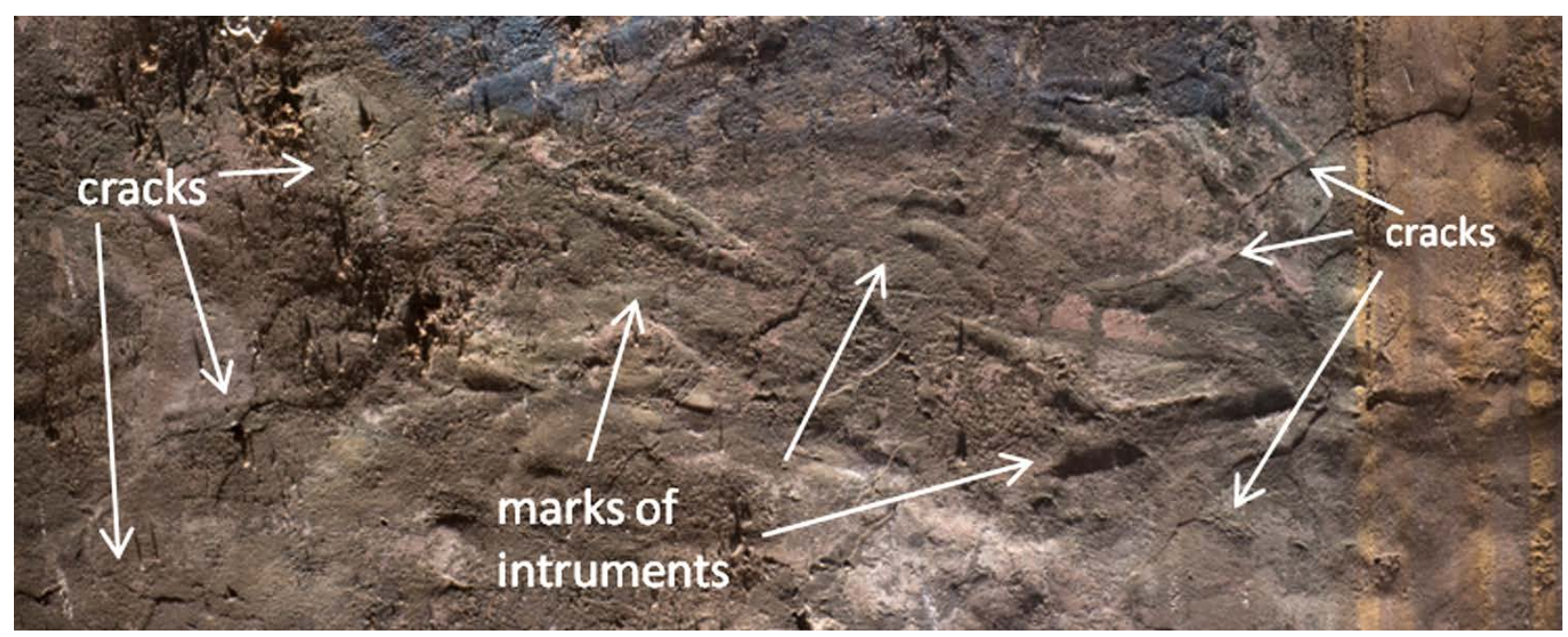

Figure 4. Scene 3, Agony in the Garden, detail. Cracks and marks of tools in the plaster.

The paintings on the north wall display the highest degree of deterioration. Rain had been infiltrating though this wall from the roof causing localized detachments in the plaster. Furthermore, pigeons have found their way through the roof and the north wall is soiled with excrements. The upper part of the painted area is overall better preserved than the decorative frames on the bottom, which are in bad condition and seem to have been refashioned several times over the centuries. In addition to these damages, we also observed drippings from a lime wash, abrasions and holes resulting from the octagonal chapel construction.

\section{Plaster work and paintings technique}

RAK photos, of the eight scenes were acquired in order to document the plaster layering method. RAK photos revealed that the plaster was laid inside the chapel walls, from left to right, by pontate rather than giornate. The Italian term giornata means "a day's work" and the term is used to describe the amount of fresco painting that is done in a single day. The last layer of plaster is applied daily to the wall in restricted areas, often following the outline of a figure. On the other hand, with the pontata method (ponte, Italian for scaffolding), the plaster is laid in wide horizontal bands corresponding to successively lower stages of the scaffolding. The only joins visible after the execution will be horizontal ones. Unlike giornate, pontate are not always synonymous of fresco technique especially in the case of large areas of paint. In this method the painter has sufficient time just to do the under drawings and to apply background or base colors on the fresh plaster. Once the plaster has dried, the painting is usually refined adding paint $a$ secco with a binder.

In the RAK photos, pontate are clearly visible in most of the scenes by the slight overlapping of the plaster on the pontate joints (Figure 3). At least two pontate are identified in scene 2, 5, 6 and 8 resulting in three horizontal painting registers. On scenes $1,3,4$, and 7 only one plaster joint was clearly observed. This could be due to the actual lack of the other pontata or, more likely, the joint was worked particularly smooth and consequently it could not be noticed on such an irregular and dirty surface. Overall, the surface of the pontate, even those close to the ground, is completed with coarse plaster. It is not as smooth as it would be expected, in particular, for the paintings on the bottom, nearest to the viewer. It is known that rough intonaci (outer plaster layer) were common in Baroque mural paintings to create textural effects [7] but this does not seem to apply for this case since it is not used for "effects" but rather without intention everywhere.

Indeed, several marks from trowels and tools used to spread the plaster can be identified, as well as cracks formed during the hardening of the intonaci, suggesting a fast execution (Figure 4).

\section{Preparatory drawings}

RAK photos also document the methods used to transfer the composition. The outlines of all of the figures revealed simply shallow lines engraved in the plaster. Curiously, only scene 4, Kiss of Judas, features a different incised drawing method on the lower pontata (Figure 5 ). The contour lines of the hands of Jesus and Judas are rounded groove, suggesting that they were made by the pressure of a pointed tool through a cartoon. On the other hand, the upper pontata with the faces of Christ and Judas shows just shallow incisions, such as the remaining scenes. Indeed, there are a number of lines indicating a free hand sketching for the contours (Figure 6). In general, the incised lines are sketchy and in some points have a grainy aspect which suggests that the plaster was almost dry. There are not substantial differences between the incised drawings and the final paintings except few small areas. While the cartoon traced with a point is immediately identified in the RAK light photo, the shallow incised lines are more difficult to identify, especially in the scenes on the north wall which are much more affected by salts, 

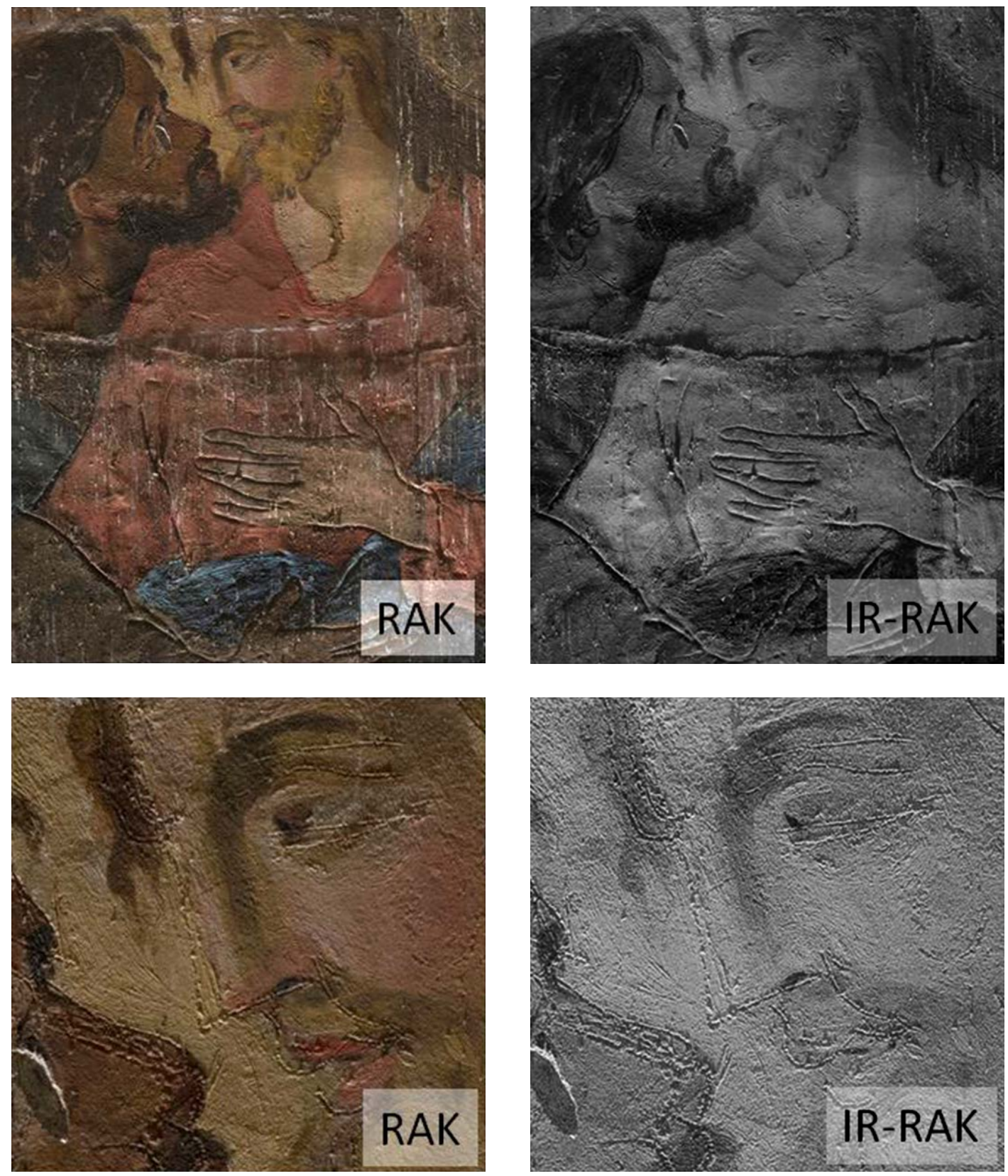

Figure 5. Scene 4, Kiss of Judas. Raking photo reveals the two types of incised drawing on the lower and upper pontata. Raking photography in the infrared (IR-RAK) increases the reading of the shallow incisions made with a pointed tool.

pigment detachments, and dirt. Thus, these scenes have also been photographed in IR-RAK. These photos can render better the incisions since the contrast between the shadow of the lines and the ground is increased thanks to the transparency of the ocher pigments (Figure 5).

\section{Paint layers}

According to Paolo and Laura Mora analysis of painting treatises from the seventeenth and eighteenth centuries, another characteristic of baroque murals was the method of applying pigments [7]. Pigments were no longer laid down in a thin almost translucent layer such as in buon fresco, but rather as an opaque mass to allow impastos of varying thickness in a manner analogous to that of oil painting. This feature is described by Andrea Pozzo in sezione decima of Perspectiva Pictorium and Architectorum, published by the first time in 1692 and re-edited during the eighteenth century [8]. These mural paintings seem to follow this aesthetic and painting method. Thick brushstrokes are visible in all the scenes, especially on the blue clothing modeling (Figure 6). It is impossible to reach this effect only applying pigments mixed with water (buon fresco technique). The addition of a binder to the pigments, such as lime or an organic substance, was necessary. The technique of lime fresco was well known from the Byzantine and Romanesque ages and it also allowed the execution time to be extended beyond that of the buon fresco technique [8]. The application of 

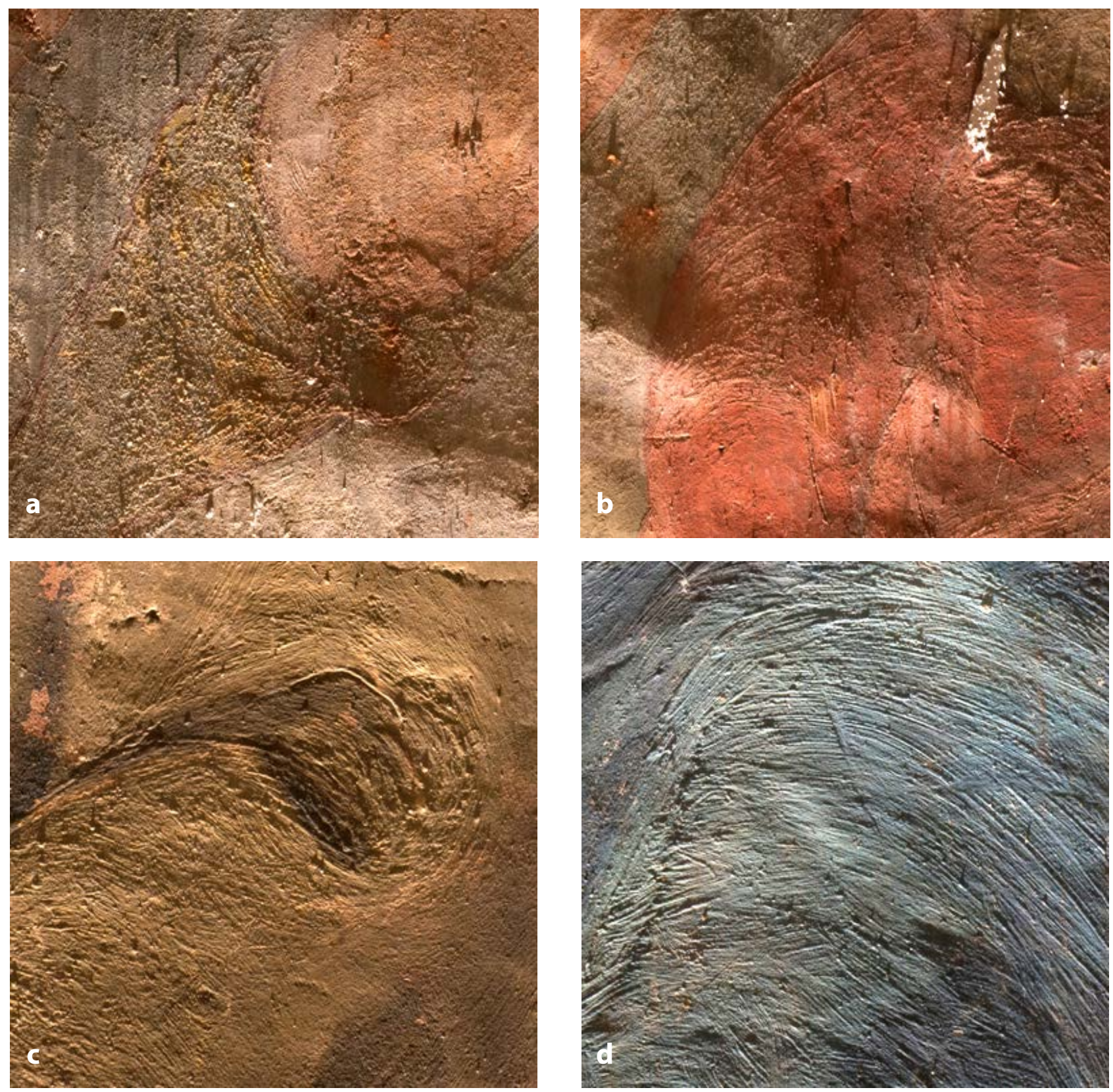

Figure 6. Scene 4 and 6, details. Raking photos document the application of thick brushstrokes of paint.

lime fresco could explain the lack of giornate in these paintings. Another hypothesis, suggested by the strong UV fluorescence of some paints (Figure 7), could be the additional use of an organic binder. Further analytical research is needed to confirm either hypothesis; however, the technical photographic documentation in both raking and UV light corroborated the use of mixed techniques in the execution of the mural paintings.

IRFC is used in art examination to distinguish retouches and to provide a tentative pigment identification. The method is not conclusive but it is recognized as a valid tool to select areas of interest for further analytical studies. The IRFC images are usually created by processing VIS and IR photos of the same scene [9]. This paper also presents the false color images acquired with the XNite BP1 filter, indicated with the acronym BP1. This filter was chosen because we required a method faster than traditional IRFC to document the mural paintings. This filter transmits visible light in the range $350-660 \mathrm{~nm}$ and infrared after $800 \mathrm{~nm}$ and can be used as an alternative to the IRFC method, however not without significant limitations. The Nikon D800, like most digital color cameras, features a CMOS imaging detector whose photosensors cannot distinguish the wavelength of the incoming light. The photosensors are covered with a CFA (color filter array) composed of tiny color filters placed over the photosensors to select only red, green or blue light. The CFA on the Nikon D800, as on the majority of digital cameras, implements the Bayer CFA scheme. Each two-by-two cell contains two green, one blue and 

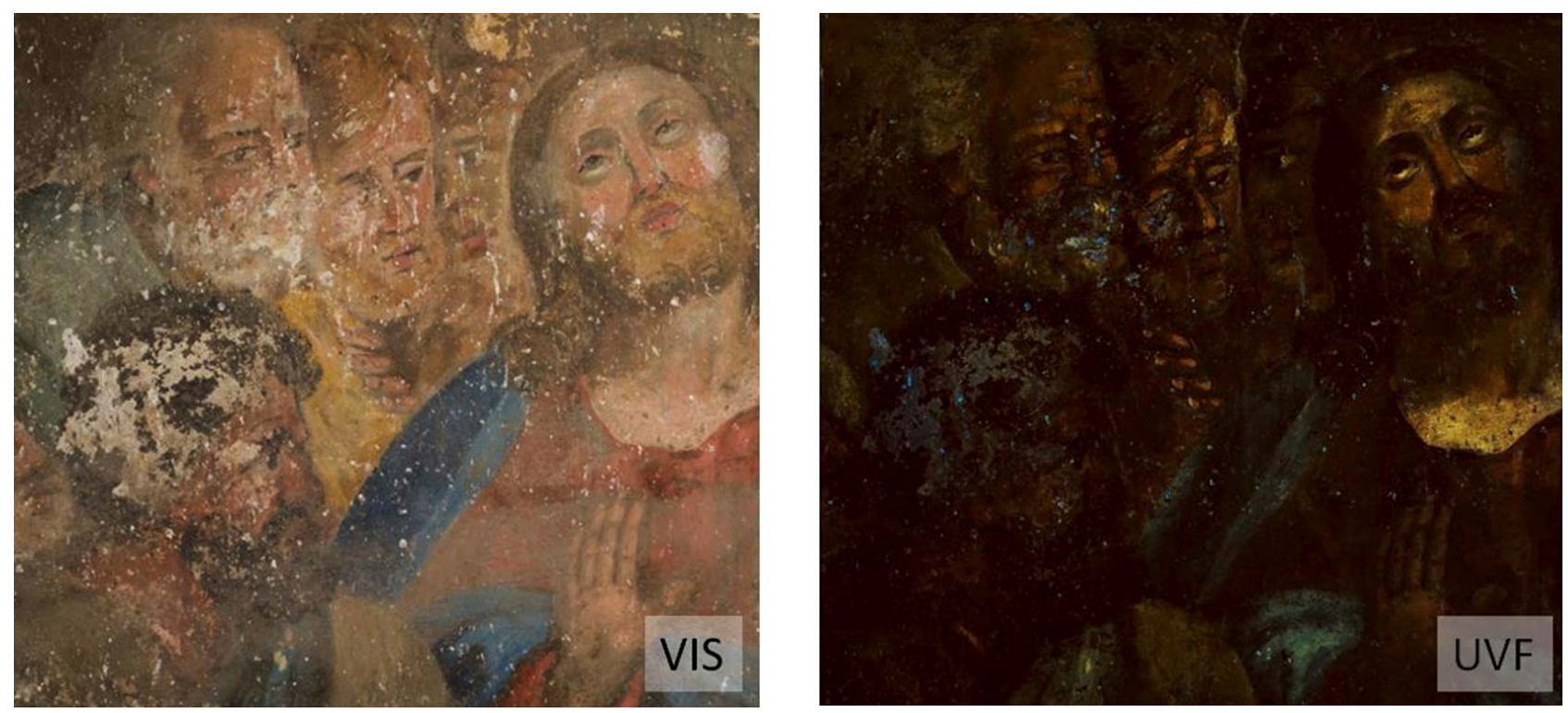

Figure 7. Scene 2, Last Supper, detail. Technical photography. The UVF photo shows strong fluorescence which could be assigned to an organic binder.

one red filter. The CFA color filters are transparent to the infrared transmitted by the XNite BP1, and, consequently, this infrared light is almost equally detected by all the photosensors. The photo that is obtained with XNite BP1 would have the infrared light contributing more to the red channel, since the far red has been cut out by the filter itself and the infrared light is the only one that can contribute to the red channel. This filter provides images that are analogous to the IRFC because the infrared and visible lights are blended together through the RGB filters of the CFA, and thus the BP1 is capable of distinguishing paints with different infrared reflectance profiles.

Compared to IRFC, BP1 is less effective since the infrared is also detected by the blue and green photosensors and the capacity to render pigments with different false color is reduced. The advantage of BP1 over IRFC is that no post-processing or editing is needed. Therefore, this method is much faster and it is particularly useful for the study of large artworks, such as mural paintings, since their documentation with IRFC would require the laborious editing of numerous VIS and IR images. Another issue with the BP1 filter is that the images obtained will always be a little bit blurred, the actual amount depending on overall exposure parameters (aperture and distance). A normal lens can focus only one spectral range at a time, visible or infrared. Therefore, if focusing is fine in the visible range, the infrared would be out of focus. This issue could be solved using an expensive apochromatic lens, but for the examination of objects at a long distance and sufficient illumination, a small aperture can minimize the blurring. The filter has been tested on a collection of 54 historical pigments laid with egg tempera (Figure 8). The method differentiates pigments with different infrared behavior, such as malachite and verdigris (both absorb infrared) from the other greens (reflect the infrared) (Figure 9). BP1 seems therefore a valid method to distinguish retouches over the two historical green pigments. The IRFC and BP1 images from the Kiss of Judas scene are shown as an example (Figure 10). Both of the images do not show any retouches. A preliminary identification of the pigments with non-destructive methods has been realized [4] and the IRFC confirmed the results. The red vest of Jesus was indeed realized with vermilion $(\mathrm{HgS})$ and the green background is green earth, while ocher was used for the brown and yellows. Further study is needed to determine the blue pigment used for the mantle of Christ.

\section{Conclusions}

Technical photography has been used for the documentation and examination of the newly discovered frescoes in the Crucifix chapel in Aci Sant'Antonio. This paper illustrated the solutions that technical photography can provide to pursue important tasks for both the documentation of state of conservation and the study of the technique used to execute these mural paintings. The most challenging part of the examination was the actual photographic documentation of the remaining portions of the fresco cycle. The results were achieved using the mosaic and panoramic methods, a wide-angle lens, and a telescopic pole. Raking light photography in both the visible and infrared range allowed for unique insights into the $18^{\text {th }}$ century painter's workshop. All the plaster work in the Crucifix Chapel was realized by large pontate, suggesting that a mixed painting technique was used. Raking light also revealed the methods used to outline the figures, which were mostly sketch lines incised on the wet, and in some cases, nearly dry plaster. Surprisingly, in one scene, we found the painter had used another kind of incised preparatory drawing, a cartoon. 

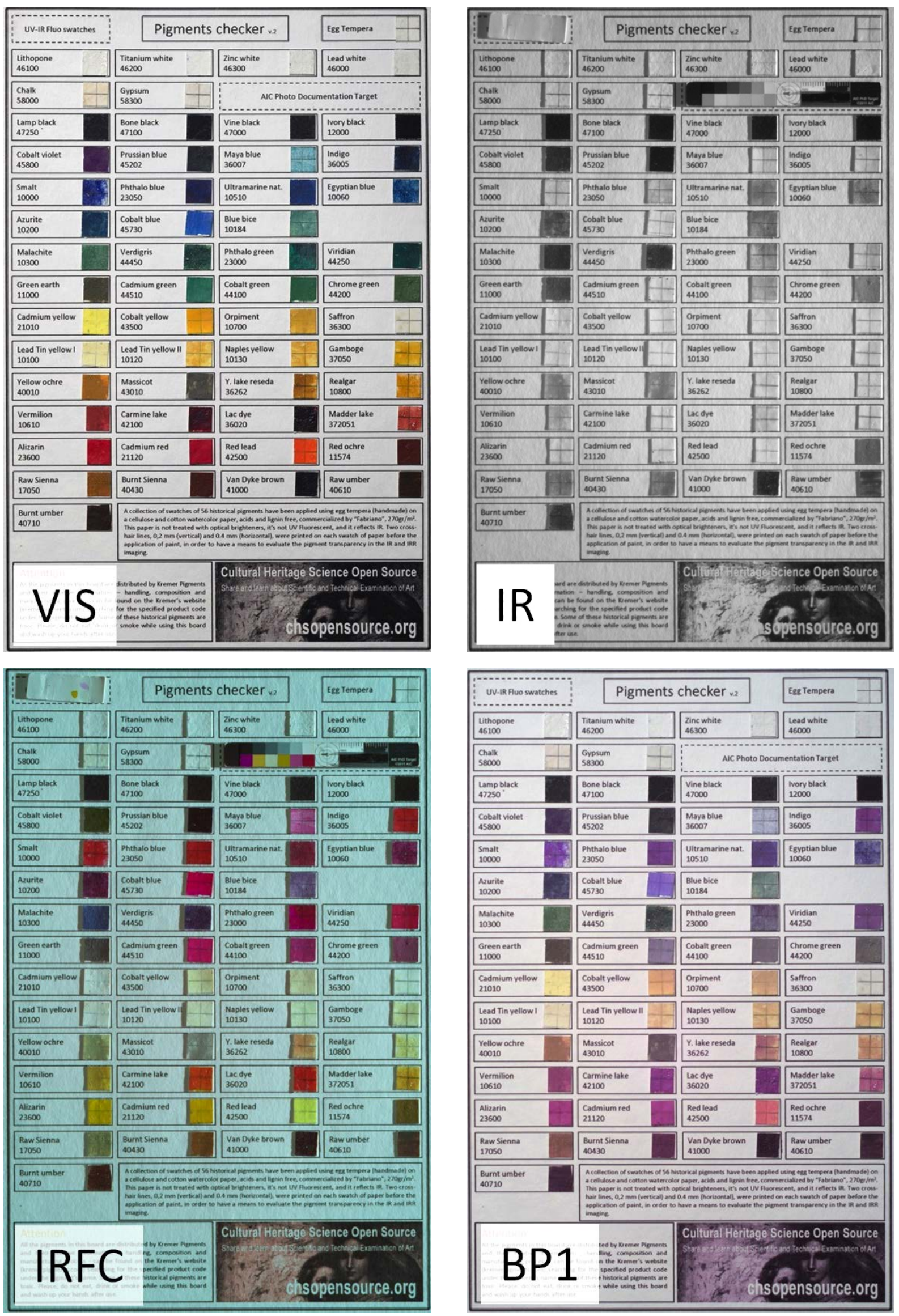

Figure 8. Pigments checker collection of 54 historical pigments laid with egg tempera and tested with the BP1 filter for infrared false color. 


\begin{tabular}{|c|c|c|c|}
\hline $\begin{array}{l}\text { Malachite } \\
10300\end{array}$ & $\begin{array}{l}\text { Verdigris } \\
44450\end{array}$ & $\begin{array}{l}\text { Phthalo green } \\
23000\end{array}$ & $\begin{array}{l}\text { Viridian } \\
\mathbf{4 4 2 5 0}\end{array}$ \\
\hline $\begin{array}{l}\text { Malachite } \\
10300\end{array}$ & $\begin{array}{l}\text { Verdigris } \\
44450\end{array}$ & $\begin{array}{l}\text { Phthalo green } \\
23000\end{array}$ & $\begin{array}{l}\text { Viridian } \\
44250\end{array}$ \\
\hline $\begin{array}{l}\text { Malachite } \\
10300\end{array}$ & $\begin{array}{l}\text { Verdigris } \\
44450\end{array}$ & $\begin{array}{l}\text { Phthalo green } \\
23000\end{array}$ & $\begin{array}{l}\text { Viridian } \\
44250\end{array}$ \\
\hline $\begin{array}{l}\text { Malachite } \\
10300\end{array}$ & $\begin{array}{l}\text { Verdigris } \\
44450\end{array}$ & $\begin{array}{l}\text { Phthalo green } \\
23000\end{array}$ & $\begin{array}{l}\text { Viridian } \\
44250\end{array}$ \\
\hline
\end{tabular}

Figure 9. Malachite, verdigris, phthalo green and viridian. Both IRFC and BP1 can differentiate the two historical green pigments (malachite and verdigris) from the modern phthalo green and viridian.

Raking photography using infrared light was shown to be an effective method to document the sketch lines. Infrared false color was applied to identify potential retouches completed before the final closure of the mural paintings behind the early $20^{\text {th }}$ century walls, and a new filter was tested to accelerate the process of acquiring infrared false color images.

\section{Acknowledgments}

The authors wish to thank Don Vittorio Rocca, the current priest of Aci Sant'Antonio parish, who has kindly supported this research. They acknowledge also the Fundação para a Ciência e Tecnologia for financial support (Post-doc grant SFRH/ BPD/63552/2009) through program QREN-POPH-typology
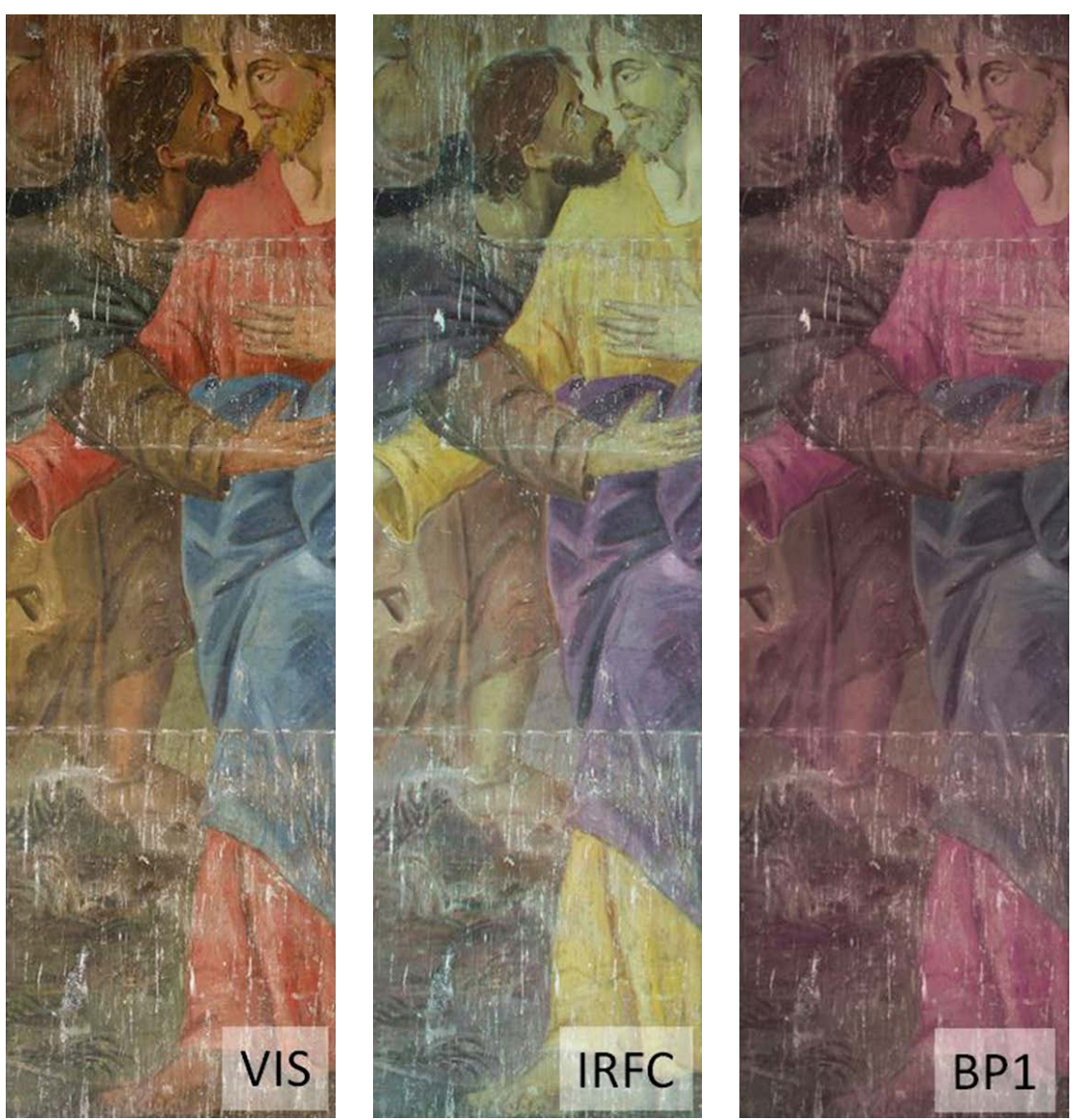

Figure 10. Scene 4, Kiss of Judas. IRFC and BP1 confirm the pigments attributions provided by previous non-invasive analysis. 
4.1, co-participated by the Social European Fund (FSE) and MCTES National Fund and Project PRIM'ART PTDC/CPCEAT/4769/2012, funded by FCT/MEC and co-funded by Fundo Europeu de Desenvolvimento Regional (FEDER) through the program COMPETE.

\section{References}

1 Cosentino, A., 'A practical guide to panoramic multispectral imaging', e-Conservation Magazine 25 (2013) 64-73, $\mathrm{http} / / / \mathrm{www} . \mathrm{e}-\mathrm{conservationline.com/content/view/1100.}$

2 Cosentino, A.; Caggiani, M. C.; Ruggiero, G.; Salvemini, F., 'Panoramic multispectral imaging: training and case studies', Bulletin - Association Professionelle de Conservateurs-Restaurateurs d'Oeuvres d'Art (2014) 7-11, http://www.brk-aproa.org/uploads/bulletins/BULLETIN\%20 2-14\%20kleur.pdf.

3 Cosentino, A., 'Panoramic infrared reflectography. Technical Recommendations', International Journal of Conservation Science 5(1) (2014) 51-60, http://www.ijcs.uaic.ro/public/ IJCS-14-05-Cosentino.pdf.

4 Cosentino, A.; Stout, S.; Di Mauro, R.; Perondi, C., 'The Crucifix Chapel of Aci Sant'Antonio: newly discovered frescoes', Archeomatica 2 (2014) 36-42, http://issuu.com/ geomedia/docs/archeomatica_2_2014? $=1225360 / 9272033$.

5 Galli, S.; Barone, G.; Crupi, V.; Majolino, D.; Migliardo, P.; Pontero, R.,'Spectroscopic techniques for the investigation of Sicilian Cultural Heritage: two different applications', in Proceedings of the NATO Advanced Research Workshop on Molecular and Structural Archaeology: Cosmetic and
Therapeutic Chemicals, ed. G. Tsoucaris, J. Lipkowski, Kluwer Academic Press, Dordrecht (2002) 85-106.

6 Cosentino A.; Stout S., 'Photoshop and multispectral imaging for art documentation', e-Preservation Science 11 (2014) 9198, http://www.morana-rtd.com/e-preservationscience/2014/ ePS_2014_a11_Cosentino.pdf.

7 Mora, P.; Mora, L.; Philippot, P., Conservation of Wall Paintings, Butterworths, London (1984).

8 Felici, A. C.; Fronterotta, G.; Piacentini, M.; Nicolais, C.; Sciuti, S.; Venditteli, M.; Vazio, C., 'The Wall paintings in the former Refectory of the Trinità dei Monti convent in Rome: relating observations from restoration and archeometric analysis to Andrea Pozzo's own treatise on the art of mural painting', Journal Cultural Heritage 5(1) (2004) 1725, doi:10.1016/j.culher.2003.07.001.

9 Cosentino, A., 'Identification of pigments by multispectral imaging; a flowchart method', Heritage Science 2 (2014) 8, doi:10.1186/2050-7445-2-8.

Received:: 11 January 2015

Accepted: 5 February 2015

Online: 9 February 2015

This work is licensed under the Creative Commons Attribution-NonCommercial-NoDerivs 3.0 Unported License. To view a copy of this license, visit http://creativecommons.org/licenses/by-nc-nd/3.0/deed.pt. 